\title{
Improving Innovative Learning Of Playgroup Teachers In Teaching-Learning Process
}

\author{
Fransisca R Sunarmi ${ }^{1}$; Apsari Fajar Prihantini²; and Mei Indrawati ${ }^{3}$ \\ ${ }^{1}$ Indonesian Education and Literature Program of STKIP BIM, ${ }^{2}$ English Education Program of STKIP \\ BIM, ${ }^{3}$ Management Faculty of Wijaya Putra University \\ ${ }^{1}$ fransisca@ stkipbim.ac.id, ${ }^{2}$ apsari@stkipbim.ac.id, ${ }^{3}$ mei.indrawati.ekonomi@gmail.com
}

\begin{abstract}
This study focused on the creativities of Playgroup teachers from PAUD Melati Ceria which had 54 students and PAUD Dewi Sartika which had 57 students. Generally those playgroup teachers came from sympathizers of PKK (Family-Welfare Program) who were not qualified teachers. According to researchers' survey, the learning used by the Playgroup teachers was still old-fashioned paradigm that made their students "dumadengar" (sitting quietly and listening) so the need for additional knowledge for the Playgroups teachers is needed. The formulation of the problems: 1) How to improve innovative learning for Playgroup students in the teaching and learning process? 2) What were the results of innovative learning for Playgroups students in the teaching and learning process? To overcome all the problems in Playgroup, the researchers took the following actions: 1) Adding knowledge about the Early Childhood Development. 2) Introducing learning models. 3) Providing knowledge about appropriate learning media. Some solutions were implemented: Providing training and assistance to principals and Playgroup teachers by holding workshops on: a) Childhood Development. b) Innovative Learning. c) Making media (props) d) Making syllabus and RKH. e) Introducing learning models f) Training in singing and music. Conclusion: Early childhood education is as a basis for instilling education. Children of such ages are quick to catch what has been given by their parents or teachers, very critical in responding to what is received. Then it needs some activities that stimulate the creativities of the Playgroup teachers and early childhood students.
\end{abstract}

Keywords: Learning, Childhood Development, Media, Models.

\section{Introduction}

Playgroup Education is a basic education applied in children before entering elementary school by giving stimulation to their education to develop physically and spiritually and also to prepare their education to the next level. Thus the applying of basic education must be appropriate. If someone wants to be a teacher especially Playgroup teachers (Bunda PAUD), they must be well prepared for their skills, knowledge of early childhood development, then Playgroup teachers who are not qualified yet must be prepared to obtain everything dealing with Playgroups (PAUD).

In Undang-Undang number: 20 year: 2003 about National Education System, in section 1 point 14 states that the early childhood education (PAUD) is the education effort for children since they were born until six years later which is obtained through educative stimulation to support children's physical and spiritual development in order to be well-prepared in achieving higher education [1]. The Playgroup teachers (Bunda PAUD) of PAUD Dewi Sartika and PAUD Melati Ceria come from sympathizers of PKK (Family-Welfare Program) who do not have special skills in teaching Playgroup students, so this research is conducted to introduce the learning-media to unqualified Playgroup teachers (Bunda PAUD), but they have to comprehend the development of the early childhood first. The workshop entitled "Improving Playgroup Teachers Quality in Teaching and Learning Process" was conducted to educate Playgroup teachers. The workshop was about early childhood development, innovative learning that introduces instructional model and media, making RKH based on syllabus and how to practice it. Through workshop and mentoring, the playgroup teachers are expected to be able to make their own learning media like a knowledge tree and a puppet stage then practice them.

Based on the description of background above, some problems formulated as follows: 1) How does the effort to improve Playgroup teachers' innovative learning in teaching and learning process of early childhood?; 2) How is the result of Playgroup teachers' innovative learning in teaching and learning process of early childhood? A teacher of early childhood must be able to apply PAIKEM which means an active, innovative, creative, effective and fun learning. In elementary school, active means creating a conducive learning atmosphere in which students are active to ask, question, and express an idea but in Playgroup (PAUD), both teachers and students are active. Playgroup teachers must be active in paying attention to the students while the 
students are active following the teaching and learning process by responding what are taught. For the term innovative, creative and fun themselves means that everything involves in learning process must be active, innovative, creative and fun. If the teachers teach by using game today, they have to change into playing a role tomorrow. The teachers do innovation, so do the students. The teachers are creative in teaching, the students are also creative in paying attention, so the teaching and learning process are fun for both teachers and students.

Through those description, the purposes of this research are: 1) to describe several ways to improve innovative learning of Playgroup teachers in teaching and learning process of early childhood; 2) to describe the innovative learning result of Playgroup teachers in teaching and learning process of early childhood.

Creating PAIKEM learning for Playgroup teachers must be well prepared that is why they have to be able to make Rencana Kegiatan Harian (RKH), a daily activity plan and it is called RPP (Rencana Pelaksanaan Pembelajaran), Learning Implementation Plan in elementary school.

\section{$2 \quad$ Review of Related Literature}

In this literature review will discuss about: 2.1 Innovative Learning, 2.2 Playgroup Teachers, 2.3 Relevant Researches, 2.4 Differences and Similarity with Other Researchers, 2.5 The Correlation between Experts arguments, Other Researchers and the Current Research. The explanation will be described as follows:

\subsection{Innovative Learning}

Innovative learning is not a learning used to be done by the teachers. They have to design the new thing in their learning process by paying attention to their students' capabilities based on their grades. According to Gagne, Briggs dan Wager (1992) Learning is a the whole activities which o help students. are designed and implemented by teachers [2]. Erikson argues that human development is a synthesis of a social development tasks [3]. Through innovative learning, the students are expected to be interested in responding all activities at that time, not to be afraid and shy in following the next learning. The teacher can bring out a longing of the students of their school. Hurlock (1978) states that playing is an activity which raises happiness without considering the last result. So that, playing is played voluntarily so students will miss the school through the teachers [4]. The most important of innovative learning refers to the concept of 4 education pillars such as learning to know, learning to be, learning to do, learning to live together. Those 4 concepts applied through active, innovative, creative, effective and fun learning (PAIKEM), so that innovative learning goals can be achieved. The key of the innovative learning is fun learning.

\subsection{The Playgroup Teachers}

The playgroup teachers are figures who help the education of early childhood [5]. They are at the government level, from national, province, district, sub-district, and village. This research involve playgroup teachers from PAUD Melati Ceria kelurahan Putat Jaya Kecamatan Sawahan dan PAUD Dewi Sartika Kelurahan Manukan Kulon Kecamatan Tandes, both of them are from Surabaya. The teachers from both playgroup do not recognize innovative learning model and media yet. The learning system still uses old fashioned paradigm, 'Dumadengar' or sit quietly and listen. This system is not suitable for children nowadays while the teachers themselves are sympathizers of PKK (Family-Welfare Program) who are lack of knowledge in education and teaching. This research is a form of community service, in the same time it is also a research which observes Playgroup teachers' teaching and learning process. The participants in workshop, training and intensive assisting of the playgroup headmasters and teachers are 18 people. Through the workshop, training and assisting intensively are expected to motivate the teachers in professional activities, improve pedagogic and managerial skills.

The steps of activities in workshop, training and assisting are 1) Workshop entitled "Innovative Learning in Early Childhood" for 3 days. Day 1: Counseling about early childhood development, innovative learning theories, learning models and media for early childhood, steps in making syllabus and RKH. Day 2: Making syllabus, RKH and learning media. Day 3: Assisting the teachers to teach based on RKH; 2) While assisting the teachers in teaching and learning for 3 months, the research is being designed.

\subsection{Relevant Researches}

Other research conducted by Hendarwati, et.al. [6] in 'Aksiologiya: Pengabdian Kepada Masyarakat' journal entitled Innovative Learning Training, The Organization of Learning Devices and The Playgroup Teachers Bookkeeping emphasizes to the teachers as the aspect of human resources in PAUD Cahaya Bunda and PAUD Mutiara Bunda because they do not have qualification in teaching early childhood, so they are lack of knowledge and experience in teaching early childhood which related to the method, media, and evaluation in learning process. Thus, the implementation of learning process is not suitable with the need and early childhood development aspect. There are 4 method used in this activities, they are: 1) First solution: Giving training and assisting in arranging learning devices. 2) Second solution: Increasing educative learning games based on the 
need analysis to operational process by giving the educative game devices both indoor and outdoor. 3) Third solution: Giving a training about early childhood innovative learning. 4) Forth solution: Discussing and assisting for the teachers in basic training bookkeeping by the practitioners.

The Correlation between Experts arguments, Other Researchers and the Current Research by Ramadhan' statements in his blog on November 11, 2018 entitled 'An Active, Innovative, Creative, Effective and Fun Learning is one of the most interesting statement and it is suitable for this research [7]. He states that:

Based on the result of the study, the high time of attention was proven to improve learning outcomes. The active and fun conditions are not enough if the learning process is not effective where students do not master anything that should be gained after teaching and learning process because learning has several learning objectives to be achieved. If the learning is only active and fun, but not effective, the learning will be like ordinary play.

His statements are suitable to be used in the next research in which Playgroup teachers must pay attention to the effectiveness of energy, time, model and media in applying the learning, so it will be useful and goals can be achieved.

\section{Data and Method}

\subsection{Data}

In collecting the data, a mentoring and observation toward playgroup teachers during teaching and learning process are conducted. Data analysis technique of playgroup teachers' activities uses descriptive data analysis technique. By describing the level or playgroup teachers' activities in implementing students learning activities on mentoring 1, 2 and 3 with the instrument below.

\subsection{Method}

This research uses a qualitative descriptive research method to improve classroom learning because the subject of this research is playgroup teachers who are not qualified in education. They are playgroup teachers of PAUD Melati Ceria Kelurahan Putat Jaya Kecamatan sawahan dan PAUD Dewi Sartika Kelurahan Manukan Kulon Kecamatan Tandes and both areas belong to Surabaya. The total numbers of the subjects are 18 people which consist of 3 Junior High School Graduates, 9 Senior High School Graduates, 1 Vocational High School Graduates, 3 Bachelors of Economics Graduates. Through this method, the learning improvement of playgroup teachers can be seen by using the instrument below.

Table 1 Assessment Instrument of Playgroup Teachers Activities

\begin{tabular}{|c|c|c|}
\hline $\begin{array}{c}\text { Numb } \\
\text { er }\end{array}$ & Observed Aspects & Score \\
\hline \multicolumn{3}{|c|}{ I. $\quad$ Preparation } \\
\hline 1 & Preparing the students to learn & $1 / 2 / 3 / 4 / 5$ \\
\hline 2 & Conducting apperception activities & $1 / 2 / 3 / 4 / 5$ \\
\hline \multicolumn{3}{|c|}{ II. Key Learning Activities } \\
\hline & A. Learning Material Mastership & \\
\hline 3 & Showing learning material mastership & $1 / 2 / 3 / 4 / 5$ \\
\hline 4 & Associating the material with other relevant knowledge & $1 / 2 / 3 / 4 / 5$ \\
\hline 5 & Delivering material clearly, based on learning hierarchy and students characteristics & $1 / 2 / 3 / 4 / 5$ \\
\hline \multirow[t]{2}{*}{6} & Associating material with the reality of life & $1 / 2 / 3 / 4 / 5$ \\
\hline & B. $\quad$ Learning Approach/Strategy & \\
\hline 7 & Applying a learning based on competencies achievement and students characteristics & $1 / 2 / 3 / 4 / 5$ \\
\hline 8 & Applying Coherent Learning & $1 / 2 / 3 / 4 / 5$ \\
\hline 9 & Mastering the class & $1 / 2 / 3 / 4 / 5$ \\
\hline 10 & Applying contextual learning & $1 / 2 / 3 / 4 / 5$ \\
\hline 11 & Applying learning which evokes a positive habit (nurturant effect) & $1 / 2 / 3 / 4 / 5$ \\
\hline \multirow[t]{2}{*}{12} & Applying learning based on time allocation & $1 / 2 / 3 / 4 / 5$ \\
\hline & C. The Using of Learning Media & \\
\hline 13 & Using learning media effectively and efficiently & $1 / 2 / 3 / 4 / 5$ \\
\hline 14 & Producing interesting messages & $1 / 2 / 3 / 4 / 5$ \\
\hline \multirow[t]{2}{*}{15} & Involving students in using learning media & $1 / 2 / 3 / 4 / 5$ \\
\hline & D. Learning which preserves students involvement & \\
\hline
\end{tabular}




\begin{tabular}{|l|l|c|}
\hline 16 & Rising students participation in learning & $1 / 2 / 3 / 4 / 5$ \\
\hline 17 & Showing open attitude toward students responses & $1 / 2 / 3 / 4 / 5$ \\
\hline 18 & Rising happiness and students enthusiasm in learning & $1 / 2 / 3 / 4 / 5$ \\
\hline & E. Process and learning result assessment & $1 / 2 / 3 / 4 / 5$ \\
\hline 19 & Monitoring learning progress & $1 / 2 / 3 / 4 / 5$ \\
\hline 20 & Conducting a final assessment based on the competencies (goals) & $1 / 2 / 3 / 4 / 5$ \\
\hline & $F$ The using of language & $1 / 2 / 3 / 4 / 5$ \\
\hline 21 & Using spoken language clearly, well and correctly & $1 / 2 / 3 / 4 / 5$ \\
\hline 22 & Delivering messages in appropriate style & $1 / 2 / 3 / 4 / 5$ \\
\hline \multicolumn{2}{|c|}{ III. CLOSING } & \\
\hline 23 & Conducting a reflection or making a summary involving the students \\
\hline 24 & $\begin{array}{l}\text { Following up by giving direction or activities or assignment as a part of } \\
\text { remedial/enrichment } \quad \text { PAN Score= Total Score/24 }\end{array}$ \\
\hline & \multicolumn{2}{|c}{} \\
\hline
\end{tabular}

The total value of the playgroup teachers activities divided by the number of Playgroup teachers evaluating activities criteria will result the average score of playgroup teachers activities. If there average scores from mentoring 2 until 3 increase, it means that playgroup teachers learning quality and innovative learning in teaching learning process also increases From the average results can be categorized as the table below.

Table 2 Assessment Criteria of Playgroup teachers' activities

\begin{tabular}{|c|c|c|}
\hline PBM Average & Criteria & Point \\
\hline $4 \leq$ Average $<5$ & Excellent & $90-100$ \\
\hline $3 \leq$ Average $<4$ & Good & $70-89$ \\
\hline $2 \leq$ Average $<3$ & Bad & $50-69$ \\
\hline $1 \leq$ Average $<2$ & Poor & $0-49$ \\
\hline
\end{tabular}

Besides playgroup teachers activities instrument, to see the success of playgroup teachers learning can also be measured from students activities instrument. By the increasing of students' activities, the activities of playgroup teachers also increase. The instruments can be seen as follows:

Table 3 Students result activities assessment instrument

\begin{tabular}{|c|l|c|}
\hline $\begin{array}{c}\text { Numb } \\
\text { er }\end{array}$ & \multicolumn{1}{|c|}{ Observed Aspects } & Score \\
\hline 1 & Paying attention to the material & $1 / 2 / 3 / 4 / 5$ \\
\hline 2 & Doing what the teachers ask & $1 / 2 / 3 / 4 / 5$ \\
\hline 3 & Repeating what the teachers ask & $1 / 2 / 3 / 4 / 5$ \\
\hline 4 & Following teachers directions & $1 / 2 / 3 / 4 / 5$ \\
\hline 5 & Being brave to do what had been taught & $1 / 2 / 3 / 4 / 5$ \\
\hline 6 & Being able to collaborate with friends & $1 / 2 / 3 / 4 / 5$ \\
\hline 7 & Having interaction with other friends & $1 / 2 / 3 / 4 / 5$ \\
\hline 8 & Doing tasks well & $1 / 2 / 3 / 4 / 5$ \\
\hline 9 & Finishing the activities & $1 / 2 / 3 / 4 / 5$ \\
\hline 10 & Reflecting the learning & $1 / 2 / 3 / 4 / 5$ \\
\hline & Total \\
\hline & Average \\
\hline
\end{tabular}

The results of the last average assessment of student activities can be seen on the table. What criteria and what point reached by the teachers can also be seen on the table as follows:

Table 4 Students activities Assessment Criteria

\begin{tabular}{|c|c|c|}
\hline Average & Criteria & Point \\
\hline $4 \leq$ Average $<5$ & Excellent & $90-100$ \\
\hline $3 \leq$ Average $<4$ & Satisfying & $70-86$ \\
\hline $2 \leq$ Average $<3$ & Less Satisfactory & $50-69$ \\
\hline $1 \leq$ Average $<2$ & Very Unsatisfactory & $0-49$ \\
\hline
\end{tabular}




\section{RESULT AND DISCUSSION}

\subsection{Result Statement}

Based on the analysis of existing data, the results of the summary assessment of playgroup teachers activities can be seen as follows:

\subsubsection{Mother of Early Childhood Activity Research Results}

Based on the data collection result which has been done and described can be explained that the results of observations from 18 playgroup teachers who applied a learning using media in the first mentoring got 46 for the total score and 2,55 for the average score and they are successfully reach a bad predicate. On the second mentoring, they got 65 for the total score and 3,64 for the average and reached a good predicate. In the third mentoring, they got 83 for the total score and 4,61 for the average and reached an excellent predicate. That shows a progress and mastery in conducting innovative learning.

4.2.2 The Research Result of Students Activities Improvement

Based on the guidelines table of data analysis, from the numbers of class B $=28$ students, only 15 students were taken randomly representing the students of class B to be processed as a data and concluded on the first mentoring. The results of the student activities were $2 \leq$ average $<3=$ Less Satisfactory. Almost all students got 50-69 for the final score. Whereas on the second mentoring, the students activities result assessments were $3 \leq$ average $<4$ = Satisfying. Most students got 70-89 for the final score. On the 3rd mentoring, the students activities result assessments were $4 \leq$ Average $<5=$ Excellent. Most students got 90-100 for the final scores. From these results, the increasing of the students activities result can be seen.

\section{CONCLUSION}

Innovative learning is needed by playgroup teachers of Melati Ceria and Dewi Sartika as the improvement in the teaching and learning process considered they are not qualified in education. The improvement was gained through a workshop entitled: Innovative Learning Improvement of Playgroup Teachers in Teaching and Learning Process. That workshop was about early childhood development, innovative learning, creating RKH, and assisting in applying RKH based on the media that had been made. After applying the knowledge that had been gained in PKM, playgroup teachers' innovative learning was improved with excellent score. With the improvement of innovative learning, the results of the students learning are also improved, from $2 \leq$ average $<3$ $=$ Less Satisfactory became $4 \leq$ average $<5=$ excellent. It means that students can follow the learning in a targeted manner

The obstacles in improving innovative learning are the lack of playgroup teachers' awareness to increase their knowledge through workshop, training, making RKH, making learning media. To realize these activities, motivation was needed. The reward was given for the teachers who got higher score based on the observation result of the playgroup teachers' activities. The advantage in processing the data using assessment instrument of teachers' and students' activities is able to measure teachers' capability in innovative learning empirically. Teachers and students activities assessment deals with final score as the result. If the average scores of the students are good, the score of teachers' activities are automatically good.

The advice given to the teachers in general is that they have to upgrade their knowledge in managing the class with innovative learning, arranging learning devices, and always using media in teaching and learning process. This research is the result of Program Kemitraan Masyarakat (PKM) which supported by DIKTI grant.

\section{References}

[1]. Sujiono, Y. N. (2009). Konsep Dasar Pendidikan Anak Usia Dini. Jakarta: PT Indeks

[2]. Gagné, R. M., Briggs, L. J., \& Wager, W. W. (1992). Principles of instructional design (4 ${ }^{\text {th }}$ ed.). Forth Worth, TX: Harcourt Brace Jovanovich College Publishers.

[3]. Erikson, E. H. (1963). Childhood and society (2nd Ed.). New York: Norton.

[4]. Hurlock, E. (1978). Perkembangan Anak (jilid 1, terjemahan). Inggris: McGraw-Hill.Inc

[5]. Sujiono dan Sujiono (2010). Bermain kreatif berbasis kecerdasan jamak. Jakarta: PT Indeks

[6]. Hendarwati dkk.2017. Pelatihan Pembelajaran Inovatif. Surabaya. Alsiologi. Jurnal Pengabdian Kepada Masyarakat

[7]. Tarmizi, Ahmad. 2018. Pembelajaran Aktif Inovatif Kreatif Efektif dan Menyenangkan. Download at https://tarmizi.wordpress.com/2008/11/11/pembelajaran-aktif-inovatif-kreatif-efektif-danmenyenangkan/11 November 2008 